\title{
THE DISTINGUISHING FEATURES OF THE PROFESSIONAL CIRCUMSTANCES OF SOCIAL WORKERS IN POLAND IN THE CONTEXT OF DIFFICULT SITUATIONS EXPERIENCED
}

The right to work is regarded as a universal right. Gainful employment is not only a source of livelihood but also a platform for the formation of human attitudes and behaviours. Through his work and his professional career man is trying to realize their life's desires and receive the resources needed to achieve and to maintain certain values. People have to deal with the challenges and problems that their work brings.

One's professional background determines one's place and role in the social process of labour. Social work is a helping profession with low social prestige and poor pay. On the other hand, professional helpers are required to have a high level of competence.

All available studies unequivocally indicate that being a social worker in Poland entails a variety of problems. Empirical studies confirm the existence of many difficulties, problems the social workers in Poland faced with. The difficulties experienced by social workers can be divided into those that are related to contacts with social assistance clients, appearing in relationships with superiors, in relationships with colleagues, the difficulties encountered by social workers in the relationships with the representatives of governmental and self-government institutions and non-governmental organizations.

Key words: professional circumstances, profession, social work, difficult situation.

Introduction. When talking about the professional circumstances of social workers in Poland, one should start with the significance of work for human beings in general.

Work has a very special meaning for people today, which results from a high unemployment rate on the one hand and, on the other hand, from the attention paid to choosing one's profession. It is through work that people achieve self-actualization and mark their presence in society. The right to work is regarded as a universal right. People work for a variety of reasons: some work just to make a living, hence they are ready to suffer humiliation and exploitation by employers and receive starvation pay) while others derive satisfaction from work because they establish an emotional bond with other employees and enjoy the atmosphere prevailing in the workplace. Still others can be considered lucky people who do not have to work for financial reasons but just for the sake of the inherent value of work [1:39].

The literature on the subject presents numerous classifications of work according to various criteria, i.e.:

- the characteristics and form of work;

- the kind of work;

- branches of science such as the philosophy of work;

- sociology of work;

- psychology of work. Psychologists defines work as performing socially useful activities in order to obtain remuneration. A. Bańka [2: 339-340] offers three definitions of work: a one-off action performed by an individual or a set of actions performed by an individual or the entirety of tasks and roles on various paths of a professional career, in an internal and external organisational environment.

Work can be classified based on various criteria. In the past, physical and mental work was distinguished. At present, many different kinds of work can be distinguished based on the extremes chosen (e.g. mechanical vs creative work), degree of interest (interest vs indifference), energy input (separately for physical and mental effort), time (one-off vs permanent), one's feelings about work (pleasant vs unpleasant), kind of responsibility (for people, for equipment), number of people (individual vs team), safety (safe vs dangerous), output (services vs products) or attitude to outcomes (comprehensive vs fragmentary).

Professional circumstances. Professional circumstances are the subject of the following branches of science: sociology, organisation and management, psychology and pedagogy.

A profession is one of the most important indicators of an individual's place and rank in the social structure. According to Weber, a profession is a complex of specialised activities enabling an individual to satisfy their needs and constituting a source of income [3: 10]. The basic characteristics of a profession include: systematically performed tasks based on specific knowledge and actions aimed at satisfying certain needs; the tasks associated with a particular profession are the basis of an employee's social status. Profession is closely related with professionalization. Problems related to profession are the subject of interest of many branches of sciences, including sociology.

The distinguishing features of the profession of a social worker. 
According to Kantowicz the profession of a social worker started to develop in Poland in the late $19^{\text {th }}$ and early $20^{\text {th }}$ century [4: 52]. This process was determined by the development of state-run forms of social welfare, institutions training such professionals as well as Polish traditions in social welfare and security.

Specialists in the profession are not necessarily full professionals (from the perspective of income), working in a particular line of work. Above all, these are people with distinct interests, suited and appropriately prepared for a specific kind of work [5: 23].

The profession of a social worker is a typical profession in the middle, situated at the heart of different dilemmas [6: 97].

Social workers in training should not only be taught but also conditioned to perform their professional role which requires an inner orientation towards working for others, an ability to understand the needs of others, etc. [4: 53].

The profession of a social worker is treated as a profession, or a profession with specific characteristics. These are as follows:

1) Having specialist education based on science-based knowledge, specific technology, professional methodology and practices;

2) Involvement in actions serving the common good and members of the professional community having autonomy in their professional activities;

3) Subordination of members of the professional community to specific ethical standards, internal rules of conduct (code of ethics);

4) Existence of self-governing organizations guarding the monopoly of the profession.

Social work is a helping profession and professional helpers are required to have a high level of competence.

The requirements concerning the education needed in this profession are specified in the Act on Social Assistance, dated 12 March 2004. Pursuant to Art. 116 (1), one must meet at least on of the following conditions to become a social worker:

- have a diploma certifying the completion of a college of social work;

- have a diploma of higher education in the field of social work;

- have completed, by 31 December 2013, a university study programme, with a major preparing for work as a social worker, in one of the following fields: pedagogy, special needs pedagogy, political science, social science, psychology, sociology, family studies.

Social workers can also successively obtain degrees of professional specialisation in social work:

- 1st degree of specialisation in social work, aimed at supplementing knowledge and improving professional skills of social workers;

- 2nd degree of specialisation in social work, aimed at expanding knowledge and improving the ability to work with certain groups of people benefiting from social assistance [7: Art. 116.1].

The responsibilities of a social worker include in particular:

1) social work;

2) analysing and assessing phenomena giving rise to the need for social assistance services, and determining the eligibility to receive such services;

3) providing information, advice and assistance with regard to solving life problems to individuals who, thanks to this assistance, will be able to solve problems giving rise to their difficult life circumstances; effective use of provisions of the law in the performance of these tasks;

4) helping people in difficult life circumstances to obtain counselling concerning the possible ways of solving their problems and provision of assistance by the relevant state and local government institutions and nongovernmental organisations; supporting these people in gaining access to assistance;

5) providing assistance in accordance with the principles of professional ethics;

6) stimulating community involvement and inspiring people to self-assistance actions in order to satisfy the basic life needs of individuals, groups and communities;

7) cooperation with other specialists in order to prevent and limit pathologies and effects of negative social phenomena; mitigation of the effects of poverty;

8) initiating new forms of assistance to individuals and families in difficult life circumstances; inspiring the establishment of institutions providing services helping improve the situation of such individuals and families;

9) co-inspiring, joint preparation, implementation and development of regional and local social assistance programmes aimed at improving the quality of life [7: Art. 119, Art. 6 (12)]

According to researchers many Polish social workers do not do any social work or social work constitutes a fraction of their vocational activity. A social worker employed in a public institution is not so much a social work specialist as a state official responsible for social affairs, including the distribution of financial assistance and services.

Trawkowska [8: 146-147] points out several characteristics of the professional community of social workers. Due to the predominance of women in this profession, providing protection and care for children becomes the main goal in the professionalization of social work. Not enough thought is given to the social work models used 
even though social workers have better and better education and training in comparison to the past. The ageing of the community of social workers is another characteristic. The maturity of social workers can be an advantage in social work because it enhances their authority and attests to their extensive experience. On the other hand, it can be an obstacle to promoting innovation in the community. Another characteristic is the experience of social workers in family life and bringing up children as well as experiencing social problems in their own families. There is also the attitude of workers to social assistance, manifested in their attachment to their place of work, a relatively long history of employment in social assistance and in their particular position as well as a considerably high level of satisfaction with work in a social assistance institution. This characteristic seems to be surprising because, as surveys show, social workers come to the profession accidentally, show great dissatisfaction with their earnings, do not want their children to do a similar job, and are convinced about the low prestige of their profession.

In their work, social workers also face numerous situations requiring them to take responsibility. This entails the need to exercise self-monitoring in the assistance actions taken as well as to maintain appropriate interpersonal relations with people under their care. Social workers work with people facing various problems and challenges. It is in the nature of the assistance process, that the social workers' opinions, attitude to clients and solutions implemented are seriously considered by clients. It also concerns behaviours, ways of action, activities and individual traits such as reliability, meticulousness, openness or responsibility. Social workers should be role models for people under their care. Thus, the responsibility associated with social work extends beyond the job description and behaviour at work [9: 62].

Social work is a difficult profession but, unfortunately, low paid and considered as low prestige in Poland [10].

Observes, the prestige of a profession is determined by factors such as level of earnings, level of education, status of the profession, tradition, familiarity of the public with the profession, public recognition and trust in representatives of the profession, the public demand for the profession, attitudes of people working in the profession, possibility to make decisions.

\section{Understanding difficult situations.}

The difficult situation is defined most often as a system of tasks (objectives), operating conditions and capabilities of an agent, where the equilibrium between these elements has been disrupted to a degree that requires a re-coordination of the agent with the environment, which causes the overloading of the system of mental regulation and leads to negative emotions.

A few types of difficult situations can be distinguished: deprivation, difficulties / challenges, overload, conflict situations and threats.

1) Situations of deprivation occur when the needs (psychological, physiological and social) of an individual are not satisfied or if an individual has not achieved the set goals (failure at work, loss of social standing). The state of acute deprivation can be caused by the loss of a friend or family member, long-lasting separation or isolation. In such situations, an individual loses a certain value, sustains some kind of damage.

2) A challenging situation occurs in the case of obstacles (redundant elements) or deficiencies (lack of a significant element) during the performance of a certain task. Both the obstacles and deficiencies have an upsetting effect on the execution of tasks, decision-making and orientation. There may be deficiency of objects (lack of proper tools or materials) or there may be a lack of information necessary for the achievement of a goal. The obstacles may include hindrances in the performance of physical activities (cramped space, barriers, blocked entrance, etc.) and mental activities (distracting factors, imprecise rules, prohibitions limiting the use of certain methods). They can take the form of external pressures - physical or social and moral (imposed pace of work, change in the direction of an activity) [11:34].

3) Overwhelming situations result from the misalignment between specific activities and the physical and/or mental possibilities of an individual who is at the brink of collapsing under the weight of the entrusted tasks. This phenomenon occurs, for example, when a low-skilled individual is given a task requiring specialist skills or an individual with poor mental resistance is exposed to strong stimuli. Long-lasting overwhelming situations lead not only to the less efficient performance of a particular task but also to exhaustion and many mental and physical disorders.

4) Conflict situations occur when an individual is subjected to opposing, moral, social or physical forces.

5) Threatening situations are understood as various dangers associated with the possible loss of something valuable to an individual. The dangers may concern the physical sphere (fear of losing one's life or health, fear of disability) or social sphere (fear of losing face, humiliation, possible criticism, losing one's position).

The challenges faced by social workers come from various sources. First, there are requirements arising from the law, i.e. tasks imposed on social workers with regard to the performance of social work. Second, social workers are required to improve their professional skills in order to ensure the professionalism of this community. Third, social workers struggle with difficulties in the performance of their tasks, which mostly refers to the limited possibilities of a local community, e.g. lack of job offers in a local job market.

Challenges faced by social workers: a review of research. 
Empirical studies confirm the existence of many problems and challenges facing social workers in Poland. The following scholars have dealt with this subject matter: K. Marzec-Holka [12] T. Kaźmierczak, Z. Kawczyńska-Butrym, [13]; B. Kromolicka [14]; D. Trawkowska [8]; M. Bieńko [6]; A. Kanios [10].

Studies conducted by Trawkowska [8: 299-325] indicate that social workers experience a variety of dilemmas and difficulties related to their professional role. Among them, the author distinguishes the following: difficulties experienced by social workers in their dealings with social assistance users; difficulties occurring in contacts with the superiors; problems in relations with consultants and co-workers; and challenges in relations with representatives of local government and central government agencies and non-governmental organisations.

It turns out that the aggressive behaviour of the clients is the fundamental problem faced by social workers when dealing with them. Three basic groups of difficulties are distinguished with regard to relations between social workers and their superiors: actions taken by superiors led to a considerable work overload, disruptions in the efficient functioning of the institution itself, disrupted flow of information and organisation of work, problems with the monitoring of social services and social service policies, pathological changes in personal relations (disrupted relations between social workers, their clients and their superiors). Social workers also indicated an overwhelming number of environments in which they work. Among problems related to the social service policies, the lack of funding for the performance of the tasks and lack of time for social work were mentioned. As far as relations with colleagues are concerned, the lack of good relations was mentioned only by $11 \%$ of all respondents. As regards problems in relations with representatives of local and central government agencies and nongovernmental organisations, respondents mentioned the excess of bureaucracy, formalised contacts between a social assistance centre and other agencies, a discernible reluctance to establish cooperation.

Surveys of work-related problems experienced by social workers, conducted by Kanios in 2016, encompassed 250 social workers employed in social assistance centres in Lublin and Lublin Province. The Questionnaire for the Subjective Assessment of Work designed by Dudek, Waszkowska, Merecz and Hanke (2004) was used in the survey.

As a result of the survey, the legal accountability and lack of adequate tools and funding turned out to be the biggest challenges. Reconciling many conflicting interests and expectations of superiors and work colleagues was also perceived as a challenge by a considerable percentage of the respondents. The constant shortage of time to do the work, the lack of opportunities to use one's potential, skills and qualifications to the full also ranked high among the problems indicated by the respondents.

The possibility of making a mistake and thus risking severe disciplinary action was frequently mentioned by social workers as a problem.

Social work is a profession that involves special risk. Surveys concerning the work safety of social workers indicate that a clear majority of these professionals $(93.8 \%)$ believe that the profession is subject to many threats including excessive responsibilities, too many regulations and orders, bureaucracy (excessive reporting), liability to disciplinary action. Threats include the aggressive behaviour and mental disorders of clients as well as their consumerist attitude and unwillingness to cooperate [15: 92-93].

The work-related, stress-generating problems of social workers occur when they do not have the sense of secure employment, when the demands of the job are beyond their ability or when they do not have enough time to perform their tasks. In consequence, social workers feel mentally overwhelmed. The lack of support from their superiors and colleagues does not help either. Thus, there is irrefutable evidence of the impact of various workrelated factors on the health of social workers. The occurrence of stress results from irregularities in important areas such as the sense of agency and control over one's work, healthy relations, support from superiors and colleagues, clearly defined requirements and sense of security [3: 305-306].

Concluding remarks. All available studies unequivocally indicate that being a social worker in Poland entails a variety of problems. The profession is underrated and does not enjoy social prestige; it is associated with the distribution of money and fraught with conflicting expectations concerning their position and the resulting social roles. This is the dark side of the profession. Surprisingly, however, social workers declare that they do not want to change their profession, that if they were to make a choice once again, they would choose the same profession, and that the desire to help other people is what motivates them in their work. Therefore, every effort should be made to create the right working conditions for social services professionals and to protect them against occupational burnout. To some extent, such efforts have already been made such as the adoption of legal regulations with regard to the supervision of social work.

\section{REFERENCES}

1. Zbyrad T. Pracownicy socjalni o sobie i swoim zawodzie / T. Zbyrad // Praca Socjalna. - 2009. - Nr 3. - S. 10-17.

2. Bańka A. Psychologia pracy / A. Bańka // J. Strelau (Eds) Psychologia. Podręcznik akademicki. - Gdańsk: Gdańskie Wydawnictwo Psychologiczne, 2008. - Tom 3. - 640 s.

3. Tarka K. Aksjologiczne korelaty funkcjonowania zawodowego pracowników socjalnych / K. Tarka // (niepublikowana praca doktorska), 2015. - $358 \mathrm{~s}$.

4. Kantowicz E. Profesjonalizm czy osobiste zaangażowanie - dylematy etyczne pracy socjalnej / E. Kantowicz // Praca Socjalna. - 2010. - Nr 2. - S. 15-23. 
5. Lepalczyk I. Niektóre pojęcia z problematyki socjalnej / I. Lepalczyk // Problem kształcenia pracowników socjalnych [red. Lepalczyk I.]. - Warszawa, 1981.

6. Bieńko M. Dylematy profesji i roli w refleksyjnym projekcie tożsamości pracownika socjalnego (na przykładzie pracowników powiatowych centrów pomocy rodzinie) / M. Bieńko // M. Rymsza (Eds.) Pracownicy socjalni i praca socjalna w Polsce. Między służbą społeczną a urzędem. - Warszawa : Wyd. Instytut Spraw Publicznych, 2012. $397 \mathrm{~s}$.

7. Ustawa o pomocy społecznej z dnia 12 marca 2004 r. - (Dz.U. Nr 64, poz. 593 z późn. zm.).

8. Trawkowska D. Pracownicy socjalni jako środowisko zawodowe. Portret czy portrety pracowników socjalnych (komentarz) / D. Trawkowska // M. Rymsza (red.) Pracownicy socjalni i praca socjalna w Polsce. Między służbą społeczną a urzędem. - Warszawa : Instytut Spraw Publicznych, 2012. - 397 s.

9. Wołk Z. Odpowiedzialność zawodowa pracownika socjalnego nieocenionym składnikiem jego kultury pracy / Z. Wołk // "Studia", Labor et Educatio - Uniwersytet Zielonogórski. - 2013. - Nr 1. - S. 61-73.

10. Kanios A. Postawy wobec pracy pracowników socjalnych a ich sytuacja zawodowa / A. Kanios// Lublin : Wyd. UMCS, 2017. - (w druku).

11. Tomaszewski T. Psychologia / T. Tomaszewski. - Warszawa : Państwowe Wydawnictwo Naukowe, 1982. - $891 \mathrm{~s}$.

12. Marzec-Holka K. Roszczenia podopiecznych pomocy społecznej a realizacja funkcji zawodu pracownika socjalnego / K. Marzec-Holka // (Eds.) Pracownicy socjalni i wolontariusze a możliwości reformy pomocy społecznej. - Bydgoszcz : Wyd. Uniwersytetu Kazimierza Wielkiego, 1998. - 246 s.

13. Kawczyńska-Butrym Z. Koncepcje opieki i zawody opiekuńcze: pracownicy socjalni i pielegniarki / Z. Kawczyńska-Butrym. - Opole : Wydawnictwo Uniwersytetu Warmińsko-Mazurskiego, 2001.- 273 s.

14. Kromolicka B. Społeczno-zawodowa rola pracownika socjalnego. Studium z pedagogiki społecznej / B. Kromolicka. - Szczecin : Wydawnictwo Uniwersytetu Szczecińskiego. - 2002. - $326 \mathrm{~s}$.

15. Bezpieczeństwo pracy pracownika socjalnego. Niech ktoś nas wysłucha / [Dunajska A., Boryczko M., Grodzicka A., Krause M.]. - Warszawa : Wydawnictwo: Difin, 2016. - 233 s.

\section{Каніос А. Специфіка професійної ситуації соціальних працівників у Польщі в контексті складних ситуацій у роботі.}

Професія сочіального працівника належить до допомагаючих професій, малооплачуваних, з низьким соиіальним престижем. Одночасно від людини, яка надає допомогу професійно, вимагається наявність високих професійних компетенцій.

У статті представлені результаті емпіричних досліджень автора, щуо підтверджують наявність безлічі проблем, з якими стикаються соціальні працівники в Польщі.

Ключові слова: професійна ситуація, професія, соціальний працівник, складна ситуація у роботі.

\section{Каниос А. Специфика профессиональной ситуации социальных работников в Польще в контексте сложных ситуаций в работе.}

Профессия социиального работника принадлежит к помогающим профессиям, малооплачиваемым, с низким сочиальным престижем. Одновременно от человека, предоставляющего помощьь

профессионально, требуется наличие высоких профессиональных компетенций. В статье представленьл результаты эмпирических исследований автора, что подтверждают существование множества проблем, с которыми сталкиваются социальные работники в Польше.

Ключевые слова: профессиональная ситуаџия, профессия, соџчильный работник, сложная ситуация 6 paботе. 